\title{
CMA president-elect nominee Dr. Ann Collins to focus on health of seniors, youth and physicians
}

Cite as: CMAJ 2019 April 15;191:E430-1. doi: 10.1503/cmaj.109-5733

Posted on cmajnews.com on Mar. 27, 2019.

t was a conversation that would shape her life. Ann Collins was a girl at the time, eldest of eight kids, growing up in rural New Brunswick.

"You're not very good at taking instruction from others," Collins' father told her. "Maybe you should look at being a physician."

It was settled. Ann Collins would become Dr. Ann Collins. "I was very focused on all of my education choices after that," Collins says. "It is something I've never regretted."

Collins has been a family doctor for more than 30 years and she is eyeing her next challenge: becoming president of the Canadian Medical Association (CMA). Collins was voted the president-elect nominee by New Brunswick doctors in February and, when her position is ratified at the CMA annual general meeting in August, she will become the official president-elect. In 2020, she will take over as president.

Collins has spent her entire career in Fredericton, save for the first three years, when she served as a medical officer with the Canadian Armed Forces in Kingston. She opened her current practice in 1989 and now serves 3000 patients. She also treats patients in nursing homes, trains family medicine residents and has worked shifts in emergency rooms.

With three decades in the same practice, Collins says she enjoys treating multiple generations of the same family. "It really is heartwarming," Collins says. "I have got to know their families and, in turn, they know about

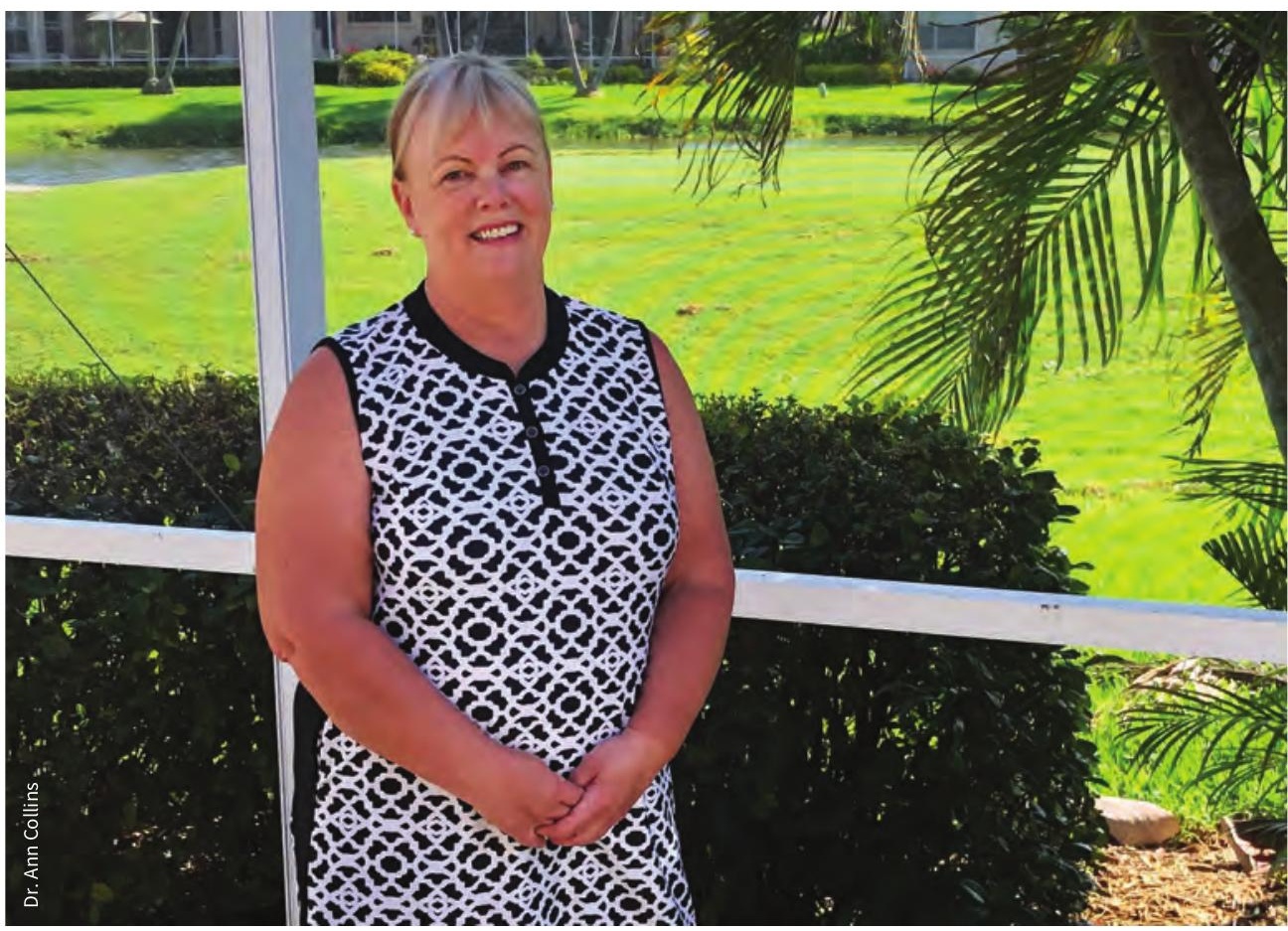

Dr. Ann Collins has been a family physician in New Brunswick for more than 30 years.

my family. We don't just share the medical aspects of the relationship; it goes beyond that."

Seniors' care makes up a large part of Collins' practice and, when she leads the CMA, she hopes to shine a spotlight on the issues that come with an aging demographic and a shortage of senior-care facilities. She also wants to shift the conversation around seniors' care. "That care needs to be started at an earlier age, to prepare to live well as a senior," Collins says. "We often think of seniors in a nursing home, but it begins much earlier than that."
On the flip side, Collins also wants to raise the profile of youth mental health. Collins says that over the last decade, family physicians are seeing more youth dealing with anxiety and other complicated mental health issues. "Oftentimes, medication is not the right treatment," says Collins. However, treatments such as cognitive behavioural therapy aren't always available, have long wait-lists and can be cost-prohibitive, she says.

Physician wellness and preventing burnout is another area Collins hopes to highlight during her tenure as president. 
When it comes to wellness, Collins takes her own seriously. "What I have always tried to do is make my family a priority," she says. Collins prioritizes time with her three grown children and her husband, John, "the rock of the family," as she calls him. She is also discovering delight in her relatively new role as grandmother to Haley, two years, and Lauren, two months.

Collins takes vacations when she can (she did this interview on the phone from Florida) and has taken up a new hobby. "Fifteen years ago, I put myself through the anguish of learning the game of golf," she says, laughing. "I will never be any good. But it has provided me with a great network of friends who aren't involved in medicine, and it gets me outside and we plan trips around it."

The CMA role isn't Collins' first in what she terms "the medical political arena." She began serving on the board of a district medical society in the early ' 90 s before getting involved with the New Brunswick Medical Society (she is a past president) and the CMA. Dr. Serge Melanson, current New Brunswick Medical Society president, says Collins' passion for the profession and her patients will serve her well as CMA president.
"Her efforts to date have contributed to the betterment of the health care system, and I am confident New Brunswick physicians will be well represented on the national and international stage," says Melanson.

Collins will have plenty of opportunity to make her home province proud as CMA president. She will be the first New Brunswicker to hold the post in 18 years. "I consider this an honour," Collins says. "It is humbling to be voted into this role."

Emily Senger, Edmonton, Alberta 